Veldkamp A, Baartman JEM, Coulthard TJ, Maddy D, Schoorl JM, Storms JEA, Temme AJAM, vanBalen $R$, van De Wiel MJ, van Gorp W, Viveen W, Westaway R, Whittaker AC.

Two decades of numerical modelling to understand long term fluvial archives: Advances and future perspectives.

Quaternary Science Reviews 2016

DOI: http://dx.doi.org/10.1016/j.quascirev.2016.10.002

Copyright:

(C) 2016. This manuscript version is made available under the CC-BY-NC-ND 4.0 license

DOI link to article:

http://dx.doi.org/10.1016/i.quascirev.2016.10.002

Date deposited:

$04 / 11 / 2016$

Embargo release date:

15 October 2017

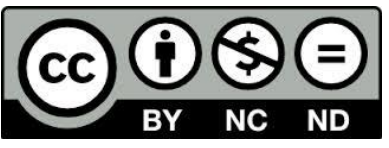

This work is licensed under a

Creative Commons Attribution-NonCommercial-NoDerivatives 4.0 International licence 


\title{
Two decades of numerical modelling to understand long term fluvial archives: advances and future perspectives.
}

\author{
Veldkamp $^{1 *}$, A., Baartman ${ }^{2}$, J.E.M., Coulthard ${ }^{3}$, T.J., Maddy ${ }^{4}$, D., Schoorl ${ }^{5}$, J.M., Storms ${ }^{6}$ J.E.A., \\ Temme $^{7}$, A.J.A.M., van Balen ${ }^{8}$, R., van De Wiel ${ }^{9}$, M.J., van Gorp ${ }^{10}$, W., Viveen ${ }^{11}$, W., \\ Westaway $^{12}$, R., Whittaker ${ }^{13}$, A.C \\ ${ }^{1}$ Faculty of Geo-Information Science and Earth Observation (ITC), University of Twente, P.O. Box 217, 7500 AE \\ Enschede, The Netherlands. a.veldkamp@utwente.nl \\ ${ }^{2}$ Soil Physics and Land Management Group, Wageningen University, PO Box 47, 6700 AA Wageningen, \\ The Netherlands. jantiene.baartman@wur.nl \\ ${ }^{3}$ School of Environmental Sciences, University of Hull, UK. T.Coulthard@ hull.ac.uk \\ ${ }^{4}$ Department of Geography, University of Newcastle, Newcastle upon Tyne, NE1 7RU, UK \\ darrel.maddy@newcastle.ac.uk \\ ${ }^{5}$ Soil Geography and Landscape group, Wageningen University, P.O. Box 47, 6700 AA Wageningen, \\ The Netherlands Jeroen.schoorl@wur.nl \\ ${ }^{6}$ Department of Geoscience and Engineering, Section Applied Geology, Delft University of Technology, \\ The Netherlands J.E.A.Storms @ tudelft.nl \\ ${ }^{7}$ Department of Geography, Kansas State University, United States, and Institute for Arctic and \\ Alpine Research, University of Colorado, Boulder, Colorado, United States arnaudtemme@ksu.nl \\ ${ }^{8}$ Dep. of Earth Sciences, VU University Amsterdam, De Boelelaan 1085, 1081 HV Amsterdam, the Netherlands \\ and TNO - Geological Survey of the Netherlands, Utrecht, r.t.van.balen@ vu.nl \\ ${ }^{9}$ Centre for Agroecology, Water and Resilience, Coventry University, UK. ab9182@ coventry.ac.uk \\ ${ }^{10}$ Groningen Institute of Archaeology (GIA), University of Groningen, Poststraat 6, 9712 ER, Groningen, \\ The Netherlands w.van.gorp@rug.nl \\ ${ }^{11}$ Sección Ingeniería de Minas e Ingeniería Geológica, Departamento de Ingeniería, Pontificia Universidad \\ Católica del Perú, San Miguel, Lima, Perú wviveen@ pucp.pe \\ ${ }^{12}$ School of Engineering, University of Glasgow, James Watt (South) Building Glasgow G12 8QQ, UK. \\ robert.westaway@gla.ac.uk \\ ${ }^{13}$ Department of Earth Science and Engineering, Imperial College, London, SW7 2AZ, UK. \\ a.whittaker@imperial.ac.uk \\ * Corresponding Author
}

\begin{abstract}
The development and application of numerical models to investigate fluvial sedimentary archives has increased during the last decades resulting in a sustained growth in the number of scientific publications with keywords, 'fluvial models', 'fluvial process models' and 'fluvial numerical models'. In this context we compile and review the current contributions of numerical modelling to the understanding of fluvial archives. In particular, recent advances, current limitations, previous unexpected results and future perspectives are all discussed. Numerical modelling efforts have demonstrated that fluvial systems can display non-linear behaviour with often unexpected dynamics causing significant delay, amplification, attenuation or blurring of externally controlled signals in their simulated record. Numerical simulations have also
\end{abstract}


demonstrated that fluvial records can be generated by intrinsic dynamics without any change in external controls. Many other model applications demonstrate that fluvial archives, specifically of large fluvial systems, can be convincingly simulated as a function of the interplay of (palaeo) landscape properties and extrinsic climate, base level and crustal controls. All discussed models can, after some calibration, produce believable matches with real world systems suggesting that equifinality - where a given end state can be reached through many different pathways starting from different initial conditions and physical assumptions - plays an important role in fluvial records and their modelling. The overall future challenge lies in the development of new methodologies for a more independent validation of system dynamics and research strategies that allow the separation of intrinsic and extrinsic record signals using combined fieldwork and modelling.

\section{Introduction}

The establishment of Fluvial Archives Group (FLAG) in 1996 has led to important developments in the understanding of the long term development of fluvial systems. Key publications that have originated through FLAG, such as the works by Maddy et al., (2001), Bridgland and Westaway (2008, 2014), have clearly demonstrated that many large scale systems appear to have comparable records with similar external controls. Concurrently, the development of numerical fluvial landscape modelling has accelerated since the late 1990s with the increasing availability of computing facilities and the further development of model algorithms and code. Influential initial attempts focused on the terrestrial erosional processes of large basins aimed at understanding large-scale and long-term erosional dynamics (Howard, 1994; Whipple and Tucker, 1999). This contributed to important discussions about the influence of climate and crustal perturbations on the landscape, the non-linear feedback mechanisms that affect fluvial systems and new insights into the concept of steady-state topography (Whipple, 2001). Research linking the application and scaling of stream power equations, which had their origin in empirical process geomorphology, led to the first catchment evolution models (such as: SIBERIA, Willgoose et al., 1991; DRAINAL, Beaumont et al., 2000; DELIM, Howard, 1994; GOLEM, Tucker and Slingerland, 1997). Concurrently, Tetzlaff and Harbaugh (1989) aimed to simulate clastic sedimentation at the grain level in downstream sink areas. This latter simulation model 
produced relatively detailed (borehole) delta and marine stratigraphy that was used to support oil exploration efforts.

Initially the gap between these modelling efforts and fieldwork-based investigations was too large to be easily bridged. Available models were often too abstract to be directly linked to the typical fluvial records studied in outcrops and boreholes in the field. As a consequence, field studies remained focused on describing and interpreting fluvial records using a separate set of conceptual models. For instance, fluvial field observations have often been analysed in the context of their environmental, tectonic and sea (base) level change records (Bridgland and Westaway, 2008, 2014; Vandenberghe et al., 2003, 2008; Stokes et al., 2012). Such an approach typically assumes, either implicitly or explicitly, that fluvial records have formed under the direct or indirect influence of such external controls. It is a common approach within the Fluvial Archive Group (FLAG) publications (see http://tolu.giub.uni-bonn.de/herget/FLAG/). One specific numerical modelling approach that has been applied frequently within the FLAG special issues (e.g., Westaway, 2001, 2002, 2007) is based on the assumption that fluvial terrace records are primarily the product of feedbacks between climate change, surface processes, and crustal processes.

Most existing fluvial numerical process models use power laws derived from empirical relationships and all have unmeasurable parameters such as erodibility and effective viscosity, which are scale-dependent and which are difficult to relate to field observations (Lague, 2014). The available numerical models often have different objects or topics of study and consequently, they also have different scales of application, scale-dependent process choices and descriptions (Temme et al., 2011a; 2016). However, increasingly numerical models attempt to produce outputs, such as terrace and basin stratigraphy that can be more readily linked to field applications.

The aim of this perspective paper is to demonstrate and outline the current progress and developments in 'fluvial archive' model development, aided by a systematic keyword analysis of an established literature database (SCOPUS) (Table 1). Specifically, the developments in 'fluvial 
models' and 'numerical fluvial models' to model fluvial archives during the 20 years of the Fluvial Archive Group (FLAG) existence will be discussed.

This will be followed by a brief characterization of a range of papers which address the modelling of fluvial archives from both hillslope, catchment and basin perspectives. We describe the types of research problems addressed by these models, and we evaluate some of the key research challenges they raise.

\section{Literature keywords search on 'fluvial models' in peer-reviewed publications}

To characterize the developments in the field of fluvial modelling a literature search using the SCOPUS database was undertaken (See Fig. 1 and Table 1). An initial search extracted the publications with keywords 'Fluvial Model'. The keyword 'Quaternary', a focal period of FLAG research, was omitted because it reduced the total sample size to 405 papers from a total of 6639 . The cumulative number of publications were plotted over time using five-year intervals (Fig. 1a). A consistent increase in publications with keywords 'Fluvial Model' is observed starting with a total of 461 publications before 1990 and cumulating to 6639 in August 2016 (Table 1). We subsequently made two subsets: 'Fluvial Process Model' and 'Fluvial Numerical Model'. Both are represented by less papers: $38.5 \%$ and $18.4 \%$ of the total 'Fluvial Model' group respectively. The 'Fluvial Process model' has a total of 148 publications before 1990 which increased up to 2557 in August 2016, while the even smaller subgroup of 'Fluvial Numerical Model' started with only 27 publications before 1990 and cumulated in 1222 in August 2016. We observe in Fig. 1b that the cumulative fraction of the 'Fluvial Model' papers using 'Numerical' as key word has steadily increased from $7 \%$ up to $18 \%$ in 2015 . A similar, but weaker development can be observed for the 'Fluvial Process Model' group of papers, increasing from 30\% up to 38\%. This indicates that researchers publishing about fluvial models use now more frequently numerical models in their research. Although the fraction of numerical modelling seems to be increasing it still represents a minority of the fluvial model investigations $(<20 \%)$. Overall around $8 \%$ of the FLAG abstracts and special issue papers use some form of numerical modelling (Table 1b).

When we refine the key word groups by adding additional keywords we observe some additional trends (Table 1). A large proportion of the papers combine 'Fluvial Model' keywords with 
external controls such as 'environment', 'climate', 'sea level', or 'base level'. Only a small fraction (maximum $3.2 \%$ ) of the fluvial model papers use key words related to intrinsic or nonlinear dynamics. The use of these keywords is more common in 'Numerical' papers, which may suggest that that numerical modelling makes researchers more aware of complex response dynamics and intrinsic versus extrinsic controls in fluvial systems.

\section{An overview of numerical models used in Fluvial archive research}

Because the review is aimed at the non-specialist in terms of numerical modelling, we have structured the numerical models according to the different depositional environments typically studied in the field. We distinguish: combined Hillslope/Fluvial records; Terrace records; Delta records; Catchment records; Basin records and finally a group of coupled models with a clear dynamic crustal component. We discuss the most relevant model contributions to support the understanding of fluvial archives over the last 20 years. We do not aim or claim to present a complete and exhaustive overview, nor will we go into detail about the specific model formulations as they have already been elaborately discussed in a recent overview publications, such as that of Tucker and Hancock (2010). The most recent model review by Temme et al. (2016) also discusses in detail the scale-dependent processes of the different landscape evolution models.

\section{Hillslope/Fluvial records}

Many headwater sediment records are often a mixture of colluvial and fluvial deposits. The LAPSUS model (Landscape Modelling at Multiple Dimensions and Scales; Schoorl et al., 2000; 2002) is one of the most commonly applied numerical models to study these types of records. The applications in regions such as KwaZulu Natal, South Africa (Temme and Veldkamp, 2009) and southeast Spain (Baartman et al., 2012a; 2012b) are the most elaborate examples spanning the last $50 \mathrm{ka}$. The WATEM -SEDEM models from Leuven University focus on soil-hillslope records only and address mainly agriculture-related case studies spanning the last millennia when tillage-induced soil redistribution became an important process (Notebaert et al., 2011; 
Haregeweyn et al., 2013). Both models were compared for a historical case study that demonstrated a similar performance in terms of generating plausible morphologies and colluvium records (Temme et al., 2011b). The challenge of LAPSUS and similar models such as the model of Wainwright (2006), lies in effectively coupling hillslope-channel dynamics. This determines the source-to-sink connectivity of the system and to what extent specific external drivers, such as large rainfall events, are registered in the long-term, downstream fluvial record (Savi et al., 2012; Michaelides and Wainwright, 2002; Bovy et al., 2016).

LAPSUS is effective in modelling different hillslope processes, including erosion by overland flow, tillage, biological and frost weathering, creep and solifluction (Temme and Veldkamp, 2009), landslides (Claessens et al., 2006) and saturated overland flow (Buis and Veldkamp, 2008). The results yield spatially explicit erosion and deposition patterns (Schoorl et al., 2004). The weakest part of LAPSUS is the lack of a realistic fluvial hydrology although first steps in that direction have been undertaken (Baartman et al., 2012b; van Gorp et al., 2015). This means that currently the model does not yield realistic sedimentology or morphology of floodplains. It does however simulate local fan morphology realistically but again without simulating detailed sedimentological patterns. There are also attempts underway to use the more detailed, but also more parameter/input demanding Wainwright (2006) model for larger spatio-temporal scales using parallel processing (PARALLEM; McGough et al., 2012). Unfortunately these attempts have not yielded realistic landscapes yet.

\section{Terrace records}

The 1-D FLUVER2 (Veldkamp and van Dijke, 2000; Tebbens et al., 2000) and Bogaart et al. (2003a, 2003b) models both aim to model longitudinal profile dynamics. FLUVER2 is more focused at the floodplain level and on the effects of climate, active crustal deformation and base level interaction (Viveen et al., 2013) while the Bogaart et al. (2003a, 2003b) model is more concerned with climate change-related river channel dynamics. Both models attempt to simulate fluvial terrace records, however FLUVER2 focuses more on terrace formation events along the whole longitudinal profile. In contrast the model of Bogaart et al. (2003a, 2003b) focuses more on river pattern change (meandering versus braiding) for individual reaches. Both models 
produce the potential events that may lead to terrace formation but both lack a realistic estimate of net terrace preservation due to the lack of a lateral dimension. The LIMTER model (Veldkamp, 1992) - more recently called TERRACE in Viveen et al. (2014) - can give some additional insight into the probability of terrace preservation and the probability of valley crosssections especially when combined with FLUVER2. Unfortunately this model is, although spatially explicit, only partly numerical with expert-based decision rules determining whether lateral and/or vertical erosion takes place (Veldkamp et al., 2002; Viveen et al., 2014).

\section{Delta records}

The controls on river delta formation are not driven exclusively by fluvial forces. The effects of wave reworking, wave and tide-induced currents, sediment transport mechanism, sediment properties (cohesive vs. non cohesive) and base level change also play a major role in delta formation. In addition to these aforementioned external (allogenic) controls, deltas also respond to internal (autogenic) controls (Karamitopoulos et al, 2014) such as channel avulsions and bifurcations. To understand, unravel and predict the complex deltaic stratigraphy there is an increasing use of process-based models that link hydrodynamics and sediment transport to better explain large- and small-scale morphodynamics (Jerolmack and Paola, 2007; Van der Vegt et al, 2016). These models are increasingly coupled to a stratigraphical module such that morphodynamics can be used to explain stratigraphic variability.

The open source Delft3D model (e.g. Geleynse et al., 2010, 2011; Edmonds and Slingerland, 2010; Hillen et al., 2014) puts emphasis on 3D delta stratigraphical records. The model has been developed in the engineering world over the past 30 years (Lesser et al, 2004; Roelvink, 2006), where many flume studies have contributed to the calibration of numerical formulations included in the hydrodynamic and sediment transport components of the model.

\section{Catchment records}


The CHILD model (Tucker et al., 2001; Tucker and Slingerland, 1997) simulates changes in topography in time and space combining both hillslope and fluvial processes. From this information, river long profiles, sediment fluxes and erosion rates can be derived. The model inputs are uplift rate and climate-related rainfall events (Tucker and Bras, 2000). Options have been proposed for both fluvial and hillslope erosion parameters, which have now been widely explored in the literature (e.g. Tucker and Whipple, 2002; Whipple and Tucker, 2002, Attal et al., 2008 amongst many). Consequently, CHILD has been used for many different case studies with a wide range of spatio-temporal domains. Several recent fluvial archive applications are particularly relevant: One study looks at how fluvial landscapes respond to climate change and to faulting to evaluate which long-term erosion laws best reproduce the channel geometry and the observed landscape response (Attal et al, 2008). Another recent study looks at the effect of wellconstrained active normal faulting on channel long-profiles and channel width in the Central Apennines of Italy (Whittaker et al., 2008). A large-scale application of the CHILD model has been developed to study the effect of Late Pleistocene climate changes on the Rhine-Meuse catchment (Van Balen et al., 2010). The focus of the latter study was on the travel time of sediment pulses and on grain size sorting in this large catchment. The predictions were compared to inferences from the stratigraphic record in the downstream part. Model input consisted of an initial topography, various erodibility factors and a regolith layer with two different grain sizes and effective precipitation. For the topography a present-day DEM of the catchment was used. The effective precipitation was taken from a global circulation model. The results showed a considerable time-delay (several thousands of years) between climatic cause and sedimentary effect. This partly blurred signal is due to the delayed arrival of separate sediment pulses that originate from the tributaries in the fluvial network.

CAESAR (Coulthard et al., 2002; van de Wiel et al., 2007) and the improved CAESARLISFLOOD (Coulthard et al., 2013) model simulate topographical change due to water and sediment movement. The model focuses on the hydrological dynamics with a high temporal resolution (event/sub event basis) and also produces surface and subsurface grain size distributions enabling the simulation of floodplain properties. Due to the use of higher resolution time series (rainfall or discharge) to simulate individual flood events, run times can be long. CAESAR applications range over time scales from individual events up to $10 \mathrm{ka}$ maximum. However, only a few applications have focused on the long-term role of climate over land use in 
affecting Holocene, fluvial, sediment records (Coulthard and Macklin, 2001), and more recently, on how climatic signals may be more evident in sedimentary archives than signals resulting over shorter time scales from active crustal deformation (Coulthard and Van de Wiel, 2013). Additionally, CAESAR has been used to explore the importance of nonlinear dynamics and floodplain dynamics in generating fluvial archives, notably how autogenic processes within drainage basins are capable of generating spurious signals in the sedimentary record (Coulthard and van de Wiel, 2007, 2012; Ziliani et al., 2013 ). The papers on nonlinear dynamics of sediment yields (Coulthard and Van De Wiel, 2007, 2013; Van De Wiel and Coulthard, 2010) and how basin response is linked to external and autogenic drivers are of direct relevance for better understanding the formation of fluvial archives.

\section{Basin records}

The SELF-SIMILARITY DOWNSTREAM MODEL (Fedele and Paola, 2007; Duller et al., 2010; Whittaker et al., 2011) produces stratigraphic grain size trends as a function of crustal subsidence and sediment supply variations at the basin level. It uses a self-similarity model for grain size fining, which was proposed in its current form by Fedele and Paola (2007). The model, as originally conceived, is two-dimensional and based on empirical observations that indicate that the grain size distributions of stream flow-dominated deposits are self-similar. For gravel grain sizes, this means that the mean and standard deviation of surface and subsurface sediments decrease at the same rate downstream (c.f. Paola et al., 1992; Paola and Seal, 1995; Duller et al., 2010; Whittaker et al., 2011). This approach is used to predict sedimentary grain sizes when sediment fluxes and accommodation space in response to active crustal deformation are known or estimated independently. The SELF-SIMILARITY DOWNSTREAM FINING MODEL has been applied to stream-flow dominated conglomerates in the Pobla Basin of the Spanish Pyrenees (Duller et al., 2010; Whittaker et al., 2011) and to understand systems such as the Fucino basin catchments in Italy (Armitage et al., 2011; Forzoni et al, 2014). A new three dimensional version of the model has recently been applied to alluvial fans in eastern California to decode the effect of late Pleistocene to Holocene climate change on sediment fluxes in such source-to-sink systems (D’Arcy et al., 2016). 
The ARMITAGE-COUPLED CATCHMENT BASIN MODEL (Armitage et al., 2011; 2013) is focused on the translation of crustal and climatic signals from source to sedimentary archives. It considers a small, frontal catchment and an alluvial fan which are separated by a vertical fault. The uplifted catchment is eroded and supplies a sediment discharge that is deposited within the basin. Erosion is mimicked by diffusive-concentrative hillslope and fluvial sediment transport equations. Depositional architecture is calculated by a mass balance approach, assuming that no erosion occurs within the depositional fan. In the model, the apex boundary condition is free to move vertically but with an imposed gradient continuity at the apex boundary. The slope of the fan is assumed to be constant. Therefore, at each time increment, a new depositional wedge is determined and selective deposition theory is used to estimate downstream stratigraphical grain size fining. The initial grain size signal is transformed downstream by selective deposition using an adapted version of self-similar solutions for downstream grain size trends. A modified ARMITAGE-COUPLED CATCHMENT BASIN MODEL version with different domain and boundary conditions has recently been applied to understanding Eocene sediment routing in the Spanish Escanilla fluvial system (Armitage et al., 2015).

\section{Coupled lithospheric and surface denudation systems}

Many models have the aim of simulating coupled lithospheric and surface denudation (Kooi and Beaumont, 1994; Beaumont et al., 2000; Van der Beek and Bishop, 2003; Codilean et al., 2006; Wickert et al., 2013). The most recent overview (Van der Beek, 2013) reviews the coupling of surface process models to other numerical models, in particular those predicting tectonic motions in the lithosphere.

There are currently two modelling approaches that have been specifically used to understand fluvial terrace records in the context of lithospheric dynamics: the lower crustal flow model by Westaway (2001, 2002) and TISC (Garcia-Castellanos, 2002; Stange et al., 2016). It should be noted that these two models are based on different, partly incompatible, assumptions regarding the rheological behaviour of the Earth's crust.

The lower crustal flow model (Westaway, 2001, 2002) calculates vertical crustal motions for continental crust with a mobile lower-crustal layer under conditions of isostatic equilibrium. It 
takes account of the effect of the non-steady-state conditions that develop within the crust as a result of changes in rates of surface processes (erosion or sedimentation). The model uses rates of surface processes before and after major climatic changes in the geological record such as the Mid Pleistocene Revolution (Mudelsee and Stattegger, 1997), and crustal properties such as crustal thickness, thickness of the mobile lower-crustal layer, and the effective viscosity of the mobile lower-crustal layer. The various lithospheric thickness parameters are constrained using geophysical studies based on seismic reflection profiles and heat flow measurements (e.g. Westaway, 2001). For the effective viscosity of the mobile, lower-crustal layer values are used that are based on the temperature at the base of this mobile layer and assumptions about is composition (Westaway, 1998). There are several applications for most continents all suggesting a plausibility of the lower crustal flow mechanism (Westaway 2002; Westaway et al., 2002). The model can also explain the observed differences between fluvial staircases on old, static, continental cratons and young, dynamic crusts (Westaway et al., 2003). An additional insight was the realization that in regions where the mobile lower crustal layer is thin $(<\sim 5 \mathrm{~km})$ one observes alternations between uplift and subsidence rather than continuous uplift or subsidence (e.g. Westaway and Bridgland, 2014).

The TISC model is capable of combining landscape evolution with plan-view lithospheric flexure (Garcia-Castellanos and Cloetingh, 2012). It can predict the amounts of erosion and sediment accumulation, resulting in a spatial redistribution of surface loads. The surface process model comprises short-range, diffusive transport on hillslopes and long-range fluvial transport in the drainage network. The efficiency of linear, short-range diffusion is determined by effective precipitation, bedrock diffusivity and topographic gradient (Kooi and Beaumont, 1994). Longrange sediment transport in rivers depends on their sediment transport capacity (e.g. undercapacity transport model, (Van der Beek and Bishop, 2003), but other models are also available) that are proportional to mean water discharge and slope. Based on constrained rheological properties (effective elastic thickness) of the lithosphere, (e.g. based on basin modeling, glacioisostasy, geodesy, etc) the model also predicts vertical lithospheric motions that result from lithospheric flexural isostatic compensation. TISC was recently applied to the Ebro river and its tributaries (Stange et al., 2016) and the results showed that isostatic motions do indeed contribute to the uplift required to explain river incision and terrace formation. 


\section{Limitations of the available models}

Every numerical model is a simplification of a real-world system based on many assumptions and empirical relationships that are often spatio-temporal and scale-dependent. Because all models are scale-dependent regarding their settings, they will require case-by-case calibration (Oreskes et al., 1994; Sapozhnikov et al., 1998). This is most obvious in the choice of model processes and the numerical description of the processes (see classic work by Kirkby, 1971). Furthermore, all models have in common that they use unmeasurable, often lumped, parameters (Crisswell et al., 2016). The 1-D models that describe longitudinal river profile dynamics all lack the lateral dimension crucial for realistically modelling of the preservation of older deposits such as terraces (Langston et al., 2015; Veldkamp et al., 2016). Furthermore, all 2-D fluvial landscape models struggle with the initial relief/profile conditions (Stange et al., 2016; Van Gorp et al., 2014). This is related to the fact that existing numerical models use forward-modelling approaches, making them sensitive to initial input which is one of the most challenging input parameters to reconstruct (Van Gorp et al., 2016).

All numerical models use simplifications and some have been dubbed reduced complexity (Larsen et al., 2014), a catch-all phrase used to describe models using significant simplifications and often empirical measurements at the expense of more physics-based first principles methods (Temme et al., 2016). Designed more to look at relationships between processes, reduced complexity models demand less input data and have relatively short run times, but their reliance upon specific assumptions and simplifications can make their validation very difficult (Oreskes et al., 1994; Schoorl et al., 2014). This is representative of the trade-off between complexity and numerical simulation feasibility, which is one underlying reason that no model is able to simulate detailed realistic landscapes over long time spans. A technical approach to reduce run time is currently sought in parallel processing (McGough et al., 2012) and has been developed for versions of the CAESAR-Lisflood model. However, this technique also requires a complete recoding of existing models, discouraging its widespread adoption. 
Despite the fact that many models have simplified empirical process descriptions, such as the inability to cope with channel widening and avulsions, they can all be calibrated to existing fluvial records (see Table 2). But typically most calibration and validation attempts are based on general catchment relationships and not on one to one comparisons (Ziliani et al., 2013). This issue touches upon the principle of equifinality. In complex systems a given end state can be reached through many different pathways starting from different initial conditions and assumptions (Beven, 1996). This may explain why most model applications (see mentioned examples Table 2) are able to yield outputs that demonstrate a general match with the known field record (Nicholas and Quine, 2010).

The 2-D spatial models all struggle with either the coupling of hillslopes and fluvial channel dynamics, or with using scale-dependent power laws (Michaelides and Wainwright, 2002; Mayor et al., 2011; Lague, 2014). There is sometimes the tendency to 'improve' models by incorporating more processes in the model (Zolezzi et al., 2012), thereby increasing the degrees of freedom and making calibration easier, knowing that equifinality will lead to plausible model results. Before considering additional processes for a new model version, their relevance needs to be independently confirmed by field-based research. An example is the realization that dynamic regolith production rates should be included in landscape evolution modelling because they can have a significant effect on catchment-wide, sediment delivery rates and morphology (Van Balen et al. 2010; Temme and Vanwalleghem, 2015). In summary, additions to model complexity and processes will ultimately increase model uncertainty in addition to model plausibility. Useful models therefore represent a trade-off between simplification of reality and the ability to simulate dynamics as realistically as possible in such a way that outcomes can be confirmed by fieldwork (Briant et al., 2016).

\section{Unexpected results from modelling exercises}

Almost all models have unexpected outcomes related to the non-linearity and delayed response of the modelled fluvial system (Coulthard and Van De Wiel, 2007, 2012; Forzoni et al., 2014; Geach et al., 2015) . For instance, there are indications that knickpoints near the headwaters of large fluvial systems were originally triggered many thousands of years ago (Demoulin, 1998; 
Beckers et al., 2015). A common observation is that fluvial systems are usually not the simple environmental archives that many conceptual models consider them to be (Vandenberghe, 2003; 2008). Modelling efforts in fact demonstrate that a spatio-temporal delay of erosion and sedimentation events along a river profile should be expected (Whittaker and Boulton, 2012). Often external controls start to interact, causing blurring of signals due to amplification or attenuation effects causing unexpected fluvial record properties (Veldkamp and Tebbens, 2001; Forzoni et al., 2014). Even a linear relationship between one external driver and observed fluvial record properties is rare. Many models and especially catchment and basin models (see Table 2) indicate that substantial signal modification (Van De Wiel and Coulthard, 2010) can (and does) take place. This blurring of environmental signals by sediment transport is thought to be driven by ubiquitous thresholds in the transport system, by autogenic behaviours, and by system noise (Jerolmack and Paola, 2010). For instance, Jerolmack and Paola (2010) suggested that external signals are shredded when their time and amplitude scales fall within the ranges of the morphodynamic disturbance, making smaller systems more sensitive to this shredding effect. Modelling has also demonstrated that simulated fluvial records can be the result of selforganizing behaviour of the fluvial/slope system without any external environmental change (Van De Wiel and Coulthard, 2007; Coulthard and Van De Wiel, 2013; Schoorl et al., 2014; Forzoni et al., 2015). This insight is still not commonly applied when interpreting fluvial records. Most field records are still viewed and interpreted via a cause and effect framework, where external changes in climate, active crustal deformation or base level control fluvial records (See for example many papers in special issues of FLAG, http://tolu.giub.uni-bonn.de/herget/FLAG/). It seems that this approach has some validity for large river systems (Bridgland and Westaway, 2008, 2014) but certainly for smaller more local systems it is a feasible alternative to consider the whole observed record to be autogenic thereby allowing no conclusions about system controls at all. Current 2-D models (See Table 2) have clearly demonstrated that river basins are always in a state of delayed response to external drivers, and always generate their own autogenic signals. These intrinsic dynamics seem especially relevant in smaller systems (Coulthard and Van de Wiel, 2013; Schoorl et al., 2014). It is therefore highly relevant to focus more on how we can separate intrinsic from extrinsic record signals.

Finally, we know that the external drivers of the fluvial system are not independent and that active crustal deformation, climate and base level change can act as coupled drivers (See 
examples Westaway, 2001, 2002; Stange et al., 2016). They can affect fluvial records in combination, which means that we have to acknowledge that not every external change leaves its own independent evidence in the fluvial record. All these insights combined imply that it would be exceptional to find simple, causal relationships reflected in the fluvial archive. This insight is illustrated by field studies where such causal relationships become less obvious when more independent age control of the fluvial record is obtained (Maddy et al., 2005; 2016).

Numerical modelling has also demonstrated that some of the basic assumptions about river behaviour, such as hydraulic scaling, probably need revisiting (Attal et al., 2011). A recent example is the importance of channel width in controlling how fluvial landscapes respond to active crustal deformation. While many models typically assume hydraulic scaling, field and modelling data show that this assumption is not always valid (Whittaker et al., 2007; Whittaker et al., 2008). Attal et al. (2008) performed an experiment where rivers cutting across faults had a fixed channel width and an experiment where channels were allowed to vary dynamically with channel gradient. This made a significant difference in how simulated landscapes record the imprint of active crustal deformation activity.

Several model applications have demonstrated that despite the many degrees of freedom it is not always easy to calibrate to existing field records (Baartman et al., 2012b; Geleynse et al., 2010). On the other hand, some models surprise by their versatility as they seem to work over a wide range of spatio-temporal scales (Coulthard et al., 2002; Temme et al., 2009; van der Vegt et al 2016). However, recent work suggests that model 'calibration' may at best only be site specific and may require re-calibration for changing climates (Coulthard and Skinner, 2016) and other factors. Other unexpected results are related to new insights in the key role of initially unconsidered factors such as the role of cohesive sediment and sediment transport mechanism on floodplain dynamics and deltaic channel pattern, or the role of sediment reworking in determining delta stratigraphy (Edmonds and Slingerland, 2010; Hillen et al., 2014; van der Vegt et al 2016). Additional unforeseen outcomes relate either to the relative unimportance of a considered process such as tillage erosion (Baartman et al., 2012a) or the long-lasting effects in the fluvial record due to a temporary local base level change as a result of lava damming (Van Gorp et al., 2013; 2016). 


\section{What is needed to advance modelling efforts (future plans)}

If we want to use existing numerical models in a more effective way we need them to be more realistic - to a certain degree. One way to achieve this is by developing an ensemble of field sites where a high resolution stratigraphy is available - i.e. stratigraphy that is well dated in time and space, and where sedimentation rates can be accurately reconstructed and sedimentation budgets are closed. Within such reference areas existing models can be tested, calibrated, compared and further developed.

In order to involve non-specialists in the numerical modelling debate they need to have access to demos and animations that illustrate the specific intrinsic fluvial dynamics and related signal amplification, attenuation, delay and shredding. There are already websites giving a general overview of many existing models. At the website of the Community Surface Dynamics Modelling System, https://csdms.colorado.edu/wiki/Model_download_portal for example, many Earth scientific models are grouped and documented. What is still lacking are simple illustrations of specific principles as discussed above. Figure 1 is a first simple attempt to illustrate why linear correlations between climate and fluvial records are not always likely. Assuming complete preservation, a typical correlation can be made using the Vandenberghe (2003) model on the timing of cold stage deposition using an existing climate curve (see green arrows). When this climate curve is modelled into an externally driven fluvial erosion/deposition curve using the FLUVER2 model a curve (purple curve, right hand side, is created that already deviates in timing and magnitude from the original climate curves. As a result, the interpretations using this curve demonstrate some deviations in depositional history for the older units. When the intrinsically driven erosion/deposition curve is included, even more deviations can be observed. Given that fluvial systems are non-linear and display a mix of intrinsic and extrinsic dynamics, the more realistic interpretations seem to be made when we take nonlinear, intrinsic behaviour into account. This behaviour cannot be determined from the field record, but requires supporting numerical model simulations (Briant et al., 2016).

One implication of tighter integration of numerical modelling with fieldwork is to allow numerical modelling to guide fieldwork. A very first attempt to guide future sampling in the 
Allier system was recently made by Veldkamp et al. (2016) using a calibrated and quasi validated FLUVER2 model.

It is also proposed that combining and linking existing models and their concepts might advance our insights (Temme et al., 2011a). An obvious idea is to develop ensemble forecasts where different models are used to explore a range of simulated outcomes, as is done in climatology and hydrology (Saleh et al., 2016; Coulthard et al., 2013). Another key area of work is to integrate "upstream" and "downstream" perspectives of fluvial systems incorporating both the source catchment and the depositional sink (e.g. Forzoni et al., 2014). The main challenge in both these cases, and more widely, will be to systematically deal with the different spatio-temporal scaling effects and basic model assumptions.

The ultimate goal of work in this area is to provide an improved understanding of the controls and dynamics of fluvial systems. However, numerical models are only one means to achieve this goal. One way to bring the numerical models closer to fieldwork is to modify them to produce additional, relevant and measurable field-related outputs such as stratigraphical records, grain size distributions, calculated ${ }^{10} \mathrm{Be}$ erosion rates (Schaller et al., 2002; 2004) or OSL inventories. There is also a clear need to target specific field studies to investigate in more detail landscape connectivity such as hillslope-channel coupling and decoupling in more detail because this mechanism will determine whether there exists a source-sink relationship in a given fluvial record (Savi et al., 2012). Such field studies help to identify intrinsic self-organization as a threshold related phenomenon (Michaelides and Wainwright, 2002), distinct from extrinsically controlled properties of fluvial records (Faulkner, 2008). Ultimately we want to understand how the records were formed and to try to infer the relevant environmental and other external drivers.

\section{Conclusions}

Numerical models have been increasingly developed and used to unlock the fluvial archive during the last decades, much of this work having been undertaken under the auspices of FLAG. Numerical modelling efforts have demonstrated that fluvial systems can display non-linear behaviour with often surprising and unforeseen dynamic effects causing significant delay, amplification, attenuation or shredding of external control signals in their simulated record. 
Numerical models have also demonstrated that fluvial records can be generated by intrinsic dynamics without any change in external controls. Many other model applications demonstrate that fluvial archives, specifically of large fluvial systems, can be convincingly simulated as a function of the interplay of (palaeo) landscape properties and extrinsic climate, base level and crustal controls. All discussed models can, after some calibration, produce convincing matches with real world systems suggesting that equifinality plays an important role in fluvial records and its modelling (Nicholas and Quine, 2010). The overall future challenge lies in the development of new methodologies for independent validation of system dynamics and research strategies that allow the separation of intrinsic and extrinsic record signals using combined fieldwork and modelling.

\section{Acknowledgements}

Handling editor Rebecca Briant is thanked for her constructive support. We thank John Armitage and a second anonymous reviewer who helped us to improve the manuscript significantly. No specific funding was involved in this research. Websites for all the models are listed in Table 2.

\section{References}

Armitage, J.A., Duller R.A., Whittaker, A.C., and Allen, P.A., 2011. Transformation of tectonic and climatic signals from source to sedimentary archive, Nature Geoscience, 4, p. 231-235.

Armitage, J.J., Dunkley Jones, T., Duller, R.A., Whittaker, A.C., , Allen, P.A., 2013. Temporal buffering of climate-driven sediment flux cycles by transient catchment responses, Earth and Planetary Science Letters, 369-370, 200 -210

Armitage J.J., Allen P.A., Burgess P.M., Hampson G.J., Whittaker A.C., Duller R.A., Michael N.A., 2015. Sediment transport model for the Eocene Escanilla sediment-routing system: Implications for the uniqueness of sequence stratigraphic architectures., Journal of Sedimentary Research, 85, 1510-1524

Attal, M., Tucker, G.E., Whittaker, A.C., Cowie, P.A., and Roberts, G.P., 2008. Modelling fluvial incision and transient landscape evolution: influence of dynamic channel adjustment, Journal of Geophysical Research, v. 113, F03013, doi:10.1029/2007JF000893 
Attal, M., Cowie, P. A., Whittaker, A. C., Hobley, D., Tucker, G. E., and Roberts, G.P., 2011. Testing fluvial erosion models using the transient response of bedrock rivers to tectonic forcing in the Apennines, Italy, Journal of Geophysical Research, 116, F02005, doi:10.1029/2010JF001875.

Baartman J.E.M., Temme A.J.A.M., Schoorl J.M., Braakhekke M.H.A., Veldkamp A., 2012a. Did tillage erosion play a role in millennial scale landscape development? Earth Surface Processes and Landforms 37, 1615-1626.

Baartman J.E.M., Van Gorp W., Temme A.J.A.M., Schoorl J.M., 2012b. Modelling sediment dynamics due to hillslope - river interactions: incorporating fluvial behaviour in landscape evolution model LAPSUS. Earth Surface Processes and Landforms 37, 923-935.

Beaumont, C., Kooi, H., Willet, S., 2000. Coupled tectonic-surface process models with applications to rifted margins and collisional orogens. Geomorphology and Global Tectonics, Summerfield, M.A., (Ed) John Wiley \& Sons, 29-55.

Beckers, A., Bovy, B., Hallot, E., Demoulin, A., 2015. Controls on knickpoint migration in a drainage network of the moderately uplifted Ardennes Plateau, Western Europe. Earth Surface Processes and Landforms 40, 357-374

Beven, K. 1996. Equifinality and uncertainty in geomorphological modelling. The Scientific Nature of Geomorphology: Proceedings of the Twenty-Seventh Binghamton Symposium in Geomorphology held 27-29 September 1996, 289-313.(eds B.L. Rhoads and C.E. Thorn), John Wiley \& Sons, Ltd

Bogaart, P.W., Van Balen, R.T. , Kasse, C., and Vandenberghe, J., 2003a. Process-based modelling of fluvial system response to rapid climate change I: model formulation and generic applications. Quaternary Science Reviews, 22, 2077-2095.

Bogaart, P.W., Van Balen, R.T. , Kasse, C., and Vandenberghe, J., 2003b. Process-based modelling of fluvial system response to rapid climate change II: application to the river Maas during the Last Glacial-Interglacial transition. Quaternary Science Reviews, 22, 2097-2110.

Bovy, B., Braun, J., Demoulin, A., 2016. A new numerical framework for simulating the control of weather and climate on the evolution of soil-mantled hillslopes. Geomorphology 263, 99-112.

Briant RM, Cohen KM, Cordier S, Demoulin A, Macklin MG, Mather A, Rixhon G, Veldkamp A, Wainwright J, Whittaker A, Wittmann H. 2016. State of Science: Does current fieldwork practice enable effective field-model comparison of fluvial landscape evolution? Earth Surface Processes and Landforms (in revision)

Bridgland, D.R., and Westaway, R., 2008. Climatically controlled river terrace staircases: A worldwide Quaternary phenomenon. Geomorphology 98, 285-315. 
Bridgland, D.R., Westaway, R., 2014. Quaternary fluvial archives and landscape evolution: A global synthesis. Proceedings of the Geologists' Association 125, 600-629.

Buis, E., Veldkamp, A., 2008. Modelling dynamic water redistribution patterns in arid catchments in the Negev Desert of Israel. Earth Surface Processes and Landforms 33, 107-122.

Claessens, L., Lowe, D.J., Hayward, B.W., Schaap, B.F., Schoorl, J.M., Veldkamp, A., 2006. Reconstructing high-magnitude/low-frequency landslide events based on soil redistribution modelling and a Late-Holocene sediment record from New Zealand. Geomorphology, 74, 29-49

Codilean, A.T., Bishop, P., Hoey, T.B., 2006. Surface process models and the links between tectonics and topography (Review) Progress in Physical Geography 30, 307-333Coulthard, T.J. and Macklin, M.G., 2001. How sensitive are river systems to climate and land-use changes? A model-based evaluation, Journal of Quaternary Science, 16, 347-351.

Coulthard, T.J., Macklin, M.G., 2001. How sensitive are river systems to climate and land-use changes? A model-based evaluation, Journal of Quaternary Science, 16, 347-351.

Coulthard, T.J., Macklin, M.G. and Kirkby, M.J., 2002. A cellular model of Holocene upland river basin and alluvial fan evolution, Earth Surface Processes and Landforms, 27, 269-288.

Coulthard, T.J. and Skinner, C.J., 2016. The sensitivity of landscape evolution models to spatial and temporal rainfall resolution, Earth Surface Dynamics Discussions doi:10.5194/esurf-2016-2, in review, 2016.

Coulthard, T.J., and Van De Wiel, M.J., 2007. Quantifying fluvial non linearity and finding selforganized criticality? Insights from simulations of river basin evolution. Geomorphology, 91, 216-235.

Coulthard, T.J., and Van De Wiel, M.J., 2012. Modelling river history and evolution. Philosophical Transactions of the Royal Society A, 370, 2123-2142.

Coulthard, T. J. and Van de Wiel, M. J. 2013. Climate, tectonics or morphology: what signals can we see in drainage basin sediment yields?, Earth Surface Dynamics, 1, 13-27,

Coulthard, T.J., Macklin, M.G. and Kirkby, M.J., 2002. A cellular model of Holocene upland river basin and alluvial fan evolution, Earth Surface Processes and Landforms, 27, 269-288.

Coulthard, T. J., Neal, J. C., Bates, P. D., Ramirez, J., de Almeida, G. A. M., Hancock, G. R., 2013. Integrating the LISFLOOD-FP 2D hydrodynamic model with the CAESAR model: implications for modelling landscape evolution. Earth Surface Processes and Landforms, 38, 1897-1906. 
Criswell, D.T., Al-Madhhachi, A.T., Fox, G.A., Miller, R.B., 2016. Deriving erodibility parameters of a mechanistic detachment model for gravels . Transactions of the ASABE 59, 145151

D’Arcy, M., Whittaker, A. C., Roda-Boluda, D. C., 2016, Measuring alluvial fan sensitivity to past climate changes using a self-similarity approach to grain size fining, Death Valley, California, Sedimentology (accepted) doi: 10.1111/sed.12308

Demoulin, A., 1998. Testing the tectonic significance of some parameters of longitudinal river profiles: the case of the Ardenne (Belgium, NW Europe). Geomorphology 24, 189-208

Duller, R.A., Whittaker, A.C., Fedele, J.J., Whitchurch, A., Springett, J., Allen, P.A., Smithells, R.L., Fordyce, S., 2010. From grainsize to tectonics, Journal of Geophysical Research, 115, F03022, doi:10.1029/2009JF001495.

Edmonds, D.A., Slingerland, R.L., 2010. Significant effect of sediment cohesion on delta morphology. Nature Geoscience 3, 105-109.

Faulkner, H., 2008. Connectivity as a crucial determinant of badland morphology and evolution. Geomorphology 100, 91-103.

Fedele, J.J. and Paola, C., 2007. Similarity solutions for fluvial sediment fining by selective deposition. Journal of Geophysical Research, 112, F02038. DOI: 10.1029/2005JF000409

Forzoni, A, Storms, J.E.A., Whittaker, C., de Jager, G., 2014. Delayed delivery from the sediment factory: modeling the impact of catchment response time to tectonics on sediment flux and fluvio-deltaic stratigraphy. Earth Surface Processes and Landforms 39, 689-704.

Forzoni, A, Storms, J.E.A., Reimann, T, Moreau, J, Jouet, G., 2015. Non-linear response of the Golo River systems, Corsica, France, to Late Quaternary climatic and sea level variations. Quaternary Science Reviews 121, 11-27.

Garcia-Castellanos, D., 2002. Interplay between lithospheric flexure and river transport in foreland basins Basin Research 14, 89-104.

Garcia-Castellanos, D., Cloetingh, S., 2012. Modeling the Interaction between Lithospheric and Surface Processes in Foreland Basins. Tectonics of Sedimentary Basins: Recent Advances. Pages 152-181.

Geach, M., Viveen, W., Mather, A.E., Stokes, M., Telfer, M.W., Fletcher, W., 2015. An integrated field and modelling study of controls on late Quaternary fluvial landscape development (Tabernas, SE Spain). Earth Surface Processes and Landforms 40, 1907-1926. 
Geleynse, N, Storms, J.E.A., Stive, M.J.F., Jagers, H.R.A., Walstra, D.J.R., 2010. Modeling of a mixed-load fluvio-deltaic system. Geophysical Research Letters 37, L05402, dx.doi.org/10.1029/2009GL04200

Geleynse, N, Storms, J.E.A., Walstra, D.J.R., Jagers, H.R.A., Wang, Z.B., Stive, M.J.F., 2011. Controls on river delta formation; insights from numerical modelling. Earth and planetary Science Letters 302, 217-226.

Guiot J, Pons A, De Beaulieu J.L., Reille M. 1989. A 140,000-year continental climate reconstruction from two European pollen records. Nature 338, 309-313.

Guiot J, de Beaulieu, J.L., Cheddadi R., David F., Ponel P., Reille M., 1993. The climate in Western Europe during the last Glacial/Interglacial cycle derived from pollen and insect remains. Palaeogeography, Palaeoclimatology, Palaeoecology: 103, 73-93.

Hillen, M.M, Geleynse, N, Storms, J.E.A., Walstra, D.J.R., and Groenenberg, R.M., 2014. Morphodynamic modeling of wave reworking of an alluvial delta and application of results in the standard reservoir modeling workflow. IAS Special Publication 46, 167-186.

Haregeweyn, N., Poesen, J., Verstraeten, G., Govers, G., de Vente, J., Nyssen, J., Decker., J., Moeyersons, J., 2013. Assessing the performance of a spatially distributed soil erosion and sediment delivery model (WATEM/SEDEM) in Northern Ethiopia. Land Degradation \& Development 24, 188-204

Howard, A.D., 1994. A detachment-limited model of drainage basin evolution. Water Resources Research 30, 261-1185.

Jerolmack, D.J. , Paola, C. 2007. Complexity in a cellular model of river avulsion. Geomorphology 91, 259-270

Jerolmack, D.J., Paola, C. 2010. Shredding of environmental signals by sediment transport. Geophysical Research Letters 37 (19), L19401 DOI: 10.1029/2010GL044638

Karamitopoulos, P., Weltje, G. J., \& Dalman, R. A. F., 2014. Allogenic controls on autogenic variability in fluvio-deltaic systems: inferences from analysis of synthetic stratigraphy. Basin Research, 26, 767-779.

Kirkby, M.J. 1971. Hillslope Process-Response Models Based on the Continuity Equation, pp. 15-30. In Slopes, Forms and Processes, Brunsden D (ed.). Institute of British Geographers, Special Publication no. 3

Kooi, H., Beaumont, C.1994. Escarpment evolution on high-elevation rifted margins: insights derived from a surface processes model that combines diffusion, advection, and reaction. Journal of Geophysical Research 99, 12,191-12,209. 
Lague, D., 2014. The stream power river incision model: Evidence, theory and beyond. Earth Surface Processes and Landforms 39, 38-61

Langston, A.L., Tucker, G.E., Anderson, R.S., 2015. Interpreting climate-modulated processes of terrace development along the Colorado Front Range using a landscape evolution model. Journal of Geophysical Research, Earth Surface, 120, 2121-2138.

Larsen, L., C. Thomas, M. Eppinga and T. Coulthard 2014. Exploratory Modeling: Extracting Causality From Complexity, Eos Trans. AGU, 95(32), 285.

Lesser, G.R., Roelvink, J.A., van Kester, J.A.T.M., Stelling, G.S. 2004. Development and validation of a three-dimensional morphological model. Coastal Engineering 51, 883-915.

Maddy, D., Macklin, M.G., Woodward, J., 2001. River Basin Sediment Systems: Archives of Environmental Change. Balkema. 503 pp.

Maddy, D., Demir, T., Bridgland, D., Veldkamp, A., Stemerdink, C., van der Schriek, T., Westaway, R. 2005. An obliquity-controlled Early Pleistocene river terrace record from western Turkey? Quaternary Research 63, 339-346

Maddy D., Veldkamp, A., Demir, T., van Gorp, W., Wijbrans, J., van Hinsbergen, D., Dekkers, M., Schreve, D., Schoorl, J., Scaife, R., Stemerdink, C., van der Schriek, T., Bridgland, D., Aytaç, A.S., 2016. The Gediz river fluvial archive: a benchmark for Quaternary Research in western Anatolia. Quaternary Science Review (accepted for publication) this issue.

Mayor, Á.G., Bautista, S., Bellot, J., 2011. Scale-dependent variation in runoff and sediment yield in a semiarid Mediterranean catchment. Journal of Hydrology 397, 128-135

Michaelides, K., Wainwright, J., 2002. Modelling the effects of hillslope-channel coupling on catchment hydrological response. Earth Surface Processes and Landforms 27, 1441-1457.

McGough, A.S., Liang, S., Rapoportas, M., Grey, R.,Vinod, G.K., Maddy, D., Trueman, A., Wainwright, J., 2012. Massively parallel landscape-evolution modelling using general purpose graphical processing units (Conference Paper). 19th International Conference on High Performance Computing, HiPC 2012, Article number 6507488, DOI:

10.1109/HiPC.2012.6507488

Mudelsee, M., Stattegger, K., 1997. Exploring the structure of the mid-Pleistocene revolution with advanced methods of time-series analysis. International Journal of Earth Sciences 86, 499511.

Nicholas, A.P., Quine, T.A., 2010. Quantitative assessment of landform equifinality and palaeoenvironmental reconstruction using geomorphic models. Geomorphology 121, 167-183 
Notebaert, B., Verstraeten, G., Ward, P., Renssen, H., Van Rompaey, A., 2011. Modeling the sensitivity of sediment and water runoff dynamics to Holocene climate and land use changes at the catchment scale. Geomorphology 126, 18-31

Oreskes N., Shrader-Frechette K., Belitz K,. 1994. Verification, validation, and confirmation of numerical models in the earth sciences. Science 263, 641-646.

Paola, C., Heller, P.L., Angevine C.L., 1992. The large-scale dynamics of grain-size variation in alluvial basins, 1: Theory. Basin Research 4, 73-90.

Paola, C., Seal, R., 1995. Grain Size Patchiness as a Cause of Selective Deposition and Downstream Fining. Water Resources Research 31, 1395-1407.

Roelvink, J.A., 2006. Coastal morphodynamic evolution techniques. Coastal Engineering 53, 277-287.

Saleh, F., Ramaswamy, V., Georgas, N., Blumberg, A.F., Pullen, 2016. A retrospective streamflow ensemble forecast for an extreme hydrologic event: A case study of Hurricane Irene and on the Hudson River basin. Hydrology and Earth System Sciences 20, 2649-2667

Sapozhnikov V.B., Murray A.B., Paola C., Foufoula-Georgiou E., 1998. Validation of braidedstream models: spatial state-space plots, self-affine scaling and island shapes. Water Resources Research 34(9), 2353-2364.

Savi, S., Schneuwly-Bollschweiler, M., Bommer-Denns, B., Stoffel, M., Schlunegger, F., 2012. Geomorphic coupling between hillslopes and channels in the Swiss Alps. Earth Surface Processes and Landforms 38, 959-969.

Schaller M., van Blanckenburg F., Veldkamp A., Tebbens L.A., Hovius N., Kubik P.W., 2002. A $30000 \mathrm{yr}$ record of erosion rates from cosmogenic 10Be in Middle European river terraces. Earth and Planetary Science Letters 204, 307-320.

Schaller, M., von Blanckenburg, F., Hovius, N., Veldkamp, A., van den Berg, M.W., Kubik, P.W., 2004. Paleoerosion rates from cosmogenic $10 \mathrm{Be}$ in a 1.3 Ma terrace sequence: Response of the river Meuse to changes in climate and rock uplift. Journal of Geology 112 (2), 127-144.

Schoorl, J.M., Sonneveld, M.P.W., Veldkamp, A., 2000. Three-dimensional landscape process modelling: the effect of DEM resolution. Earth Surface Processes and Landforms 25, 1025-1034.

Schoorl, J.M., Veldkamp, A., Bouma, J., 2002. Modeling water and soil redistribution in a dynamic landscape context. Soil Science Society of America Journal 66, 1610-1619.

Schoorl, J.M., Boix Fayos, C., de Meijer, R.J., van der Graaf, E.R., Veldkamp, A., 2004. The Cs137 technique applied to steep Mediterranean slopes (Part II): landscape evolution and model calibration. Catena 57 (1): 35-54. 
Schoorl, J.M., Temme, A.J.A.M., Veldkamp, A., 2014. Modelling centennial sediment waves in an eroding landscape - catchment complexity. Earth Surface Processes and Landforms 39 15261537.

Stange, K.M., Van Balen, R., Garcia-Castellanos, D., S., Cloetingh. 2016. Numerical modelling of terrace staircase formation in the Quaternary drainage system of the southern Pyrenees, Ebro basin, NE Iberia. Basin Research 28, 124-146.

Stokes, M., Cunha, P.P., Martins, A.A. 2012. Techniques for analysing Late Cenozoic river terrace sequences (Editorial) Geomorphology. 165-166, 1-6

Tebbens L.A., Veldkamp A., van Dijke J.J., Schoorl J.M., 2000. Modeling longitudinal-profile development in response to Late Quaternary tectonics, climate and sea-level changes: the River Meuse. Global and Planetary Change 27, 165 - 186.

Temme, A.J.A.M., Veldkamp, A., 2009. Multi-process Late Quaternary landscape evolution modelling reveals lags in climate response over small spatial scales. Earth Surface Processes and Landforms, 34, 573-589.

Temme, A.J.A.M., Claessens, L., Veldkamp, A., Schoorl, J.M., 2011a. Evaluating choices in multi-process landscape evolution models. Geomorphology, 125, 271-281.

Temme, A.J.A.M., Peeters, I., Buis, E., Veldkamp, A., Govers, G., 2011b. Comparing landscape evolution models with quantitative field data at the millennial time scale in the Belgian loess belt. Earth Surface Processes and Landforms, 36, 1300-1312.

Temme A.J.A.M., Baartman J.E.M., Schoorl J.M., 2009. Can uncertain landscape evolution models discriminate between landscape responses to stable and changing future climate? A millennial-scale test. Global and Planetary Change 69, 48 - 58.

Temme, A.J., Vanwalleghem, T., 2015. LORICA-A new model for linking landscape and soil profile evolution: development and sensitivity analysis. Computers \& Geosciences, 90, 131-143.

Temme A.J.A.M., Armitage J., Attal, M., van Gorp W., Coulthard T., Schoorl J.M., 2016.

Choosing and using landscape evolution models to inform field-stratigraphy and landscape reconstruction studies. Earth Surface Processes and Landforms (Under revision)

Tetzlaff, D.M., Harbaugh, J.W., 1989. Simulating clastic sedimentation. New York, NY; Van Nostrand Reinhold Co. Inc.

Tucker G.E., Slingerland, R, 1997. Drainage basin responses to climate change. Water Resource Research 33: 2031-2047. 
Tucker, G.E., Lancaster, S., Gasparini, N., Bras, R., 2001. The Channel-Hillslope Integrated Development model (CHILD). In: Landscape Erosion and evolution Modeling, Harmon R.S., Doe III, W.W., (Eds) Kluwer Academic/Plenum Publishers: New York.

Tucker G.E., Bras, R.L., 2000. A stochastic approach to modelling the role of rainfall variability in drainage basin evolution. Water Resources Research 36, 1953-1964.

Tucker G.E., Hancock G.R., 2010. Modelling landscape evolution. Earth Surface Processes and Landforms 35, 28-50.

Tucker, G. E. Whipple, K. X., 2002. Topographic outcomes predicted by stream erosion models: Sensitivity analysis and intermodel comparison. Journal of Geophysical Research. Solid Earth. 107, Pages ETG 1-1-ETG 1-16. DOI: 10.1029/2001JB000162

Van Balen, R.T., Busschers, F., Tucker, G., 2010. Modeling the response of the Rhine-Meuse fluvial system to Late Pleistocene climate change. Geomorphology 114, 440-452.

Vandenberghe, J., 2003. Climate forcing of fluvial system development: An evolution of ideas Quaternary Science Reviews, 22, 2053-2060.

Vandenberghe, J., 2008. The fluvial cycle at cold-warm-cold transitions in lowland regions: A refinement of theory. Geomorphology, 98, 275-284.

Van der Beek, P., Bishop, P., 2003. Cenozoic river profile development in the Upper Lachlan catchment (SE Australia) as a test quantitative fluvial incision models. Journal of Geophysical Research B: Solid Earth 108, ETG 11-1 - 11-27

Van der Beek, P., 2013. Modelling Landscape Evolution (Book Chapter) Environmental Modelling: Finding Simplicity in Complexity: Second Edition, Pages 309-331

Van der Vegt, H., Storms, J.E.A., Walstra, D.J.R. and Howes, N.C., 2016. Can bed load transport drive varying depositional behaviour in river delta environments?, Sedimentary Geology (In Press), doi: 10.1016/j.sedgeo.2016.08.009.

Van De Wiel, M.J., Coulthard, T. J., Macklin, M.G. and Lewin, J., 2007. Embedding reach-scale fluvial dynamics within the CAESAR cellular automaton landscape evolution model, Geomorphology, 90, 283-301.

Van De Wiel, M.J., Coulthard, T.J., 2010. Self organized criticality in river basins: Challenging sedimentary records of environmental change. Geology, 38, 87-90.

Van Gorp W., Veldkamp A., Temme A.J.A.M., Maddy D., Demir T., Van der Schriek T., Reimann T., Wallinga J., Wijbrans J., Schoorl J.M., 2013. Fluvial response to Holocene volcanic damming and breaching in the Gediz and Geren rivers, western Turkey. Geomorphology 201: 430-448 
Van Gorp W., Temme A.J.A.M., Veldkamp A., Schoorl J.M., 2015. Modelling long-term (300 ka) upland catchment response to multiple lava damming events. Earth Surface Processes and Landforms 40, 888-900.

Van Gorp W., Schoorl, J.M., Temme A.J.A.M., Reiman T., Wijbrans J.R., Maddy D., Demir T., Veldkamp A., 2016. Catchment response to lava dam influenced base level change: an integrated field and landscape evolution modelling approach. Earth Surface Processes and Landforms (accepted for publication).

Veldkamp A., 1992. A 3-D model of fluvial terrace development in the Allier basin (Limagne. France). Earth Surface Processes and Landforms 17, 487-500.

Veldkamp A., van Dijke, J.J., 2000. Simulating internal and external controls on fluvial terrace stratigraphy : a qualitative comparison with the Maas record. Geomorphology 33, 225 - 236.

Veldkamp A., Tebbens L.A., 2001. Registration of abrupt climate changes within fluvial systems : insights from numerical modelling experiments. Global and Planetary Change 28, 129 - 144.

Veldkamp A., Van den Berg M.W., Van Dijke J.J., Van den Berg van Saparoea R.M., 2002. Reconstructing Late Quaternary fluvial process controls in the upper Aller Valley (North Germany) by means of numerical modelling. Geologie en Mijnbouw, 81, 375-388

Veldkamp, A., Schoorl, J.M., Viveen, W., 2016. Predicting location-specific fluvial archives with the FLUVER2 model for the late Quaternary Allier River (France) . Earth Surface Processes and Landforms (accepted for publication)

Viveen W., Schoorl J.M., Veldkamp A., van Balen R.T., Desprat S., Vidal-Romani J.R., 2013. Reconstructing the interacting effects of base level, climate, and tectonic uplift in the lower Miño River terrace record: A gradient modelling evaluation. Geomorphology 186, 96-118.

Viveen, W., Schoorl, J.M., Veldkamp, A., van Balen, R.T., 2014. Modelling the impact of regional uplift and local tectonics on fluvial terrace preservation. Geomorphology 210, 119-135.

Wainwright, J. 2006. Degrees of separation: Hillslope-channel coupling and the limits of palaeohydrological reconstruction. Catena, 66 , 93-106.

Westaway, R., 1998. Dependence of active normal fault dips on lower-crustal flow regimes, Journal of the Geological Society, London, 155, 233-253.

Westaway, R., 2001. Flow in the lower continental crust as a mechanism for the Quaternary uplift of the Rhenish Massif, north-west Europe. In: Maddy, D., Macklin, M.G., Woodward, J.C. (Eds.), River Basin Sediment Systems: Archives of Environmental Change. Balkema, Abingdon, England, pp. 87-167. 
Westaway R., 2002. Long term river terrace sequences: evidence for global increase in surface uplift rates in the Late Pliocene and early Middle Pleistocene caused by flow in the lower continental crust induced by surface processes. Netherlands Journal of Geosciences 81, 305-328.

Westaway, R., 2007. Improved modelling of the Quaternary evolution of the Gulf of Corinth, incorporating erosion and sedimentation coupled by lower-crustal flow. Tectonophysics 440, 6784.

Westaway, R., Maddy, D., Bridgland, D., 2002. Flow in the lower continental crust as a mechanism for the quaternary uplift of south-east England: Constraints from the Thames terrace record. Quaternary Science Reviews 21, 559-603.

Westaway, R., Bridgland, D.R., Mishra, S., 2003. Rheological differences between Archaean and younger crust can determine rates of Quaternary vertical motions revealed by fluvial geomorphology. Terra Nova, 15, 287-298.

Westaway, R., Bridgland, D.R., 2014. Relation between alternations of uplift and subsidence revealed by Late Cenozoic fluvial sequences and physical properties of the continental crust. Boreas, 43, 505-527.

Whipple, K.X., 2001. Fluvial Landscape Response Time: How Plausible Is Steady-State Denudation? American Journal of Science 301: 313-325

Whipple, K.X., Tucker, G.E., 1999. Dynamics of the stream-power river incision model; implications for height limits of mountain ranges, landscape response timescales, and research needs. Journal of Geophysical Research, B, Solid Earth and Planets 104: 17661-17674.

Whipple, K.X., Tucker, G.E., 2002. Implications of sediment-flux-dependent river incision models for landscape evolution. Journal of Geophysical Research, B, Solid Earth 107, ETG 3-1ETG 3-20. DOI: 10.1029/2000JB000044

Whittaker, A.C., Cowie P.A., Attal, M., Tucker G.E. and Roberts, G., 2007, Bedrock channel adjustment to tectonic forcing: Implications for predicting river incision rates, Geology, 35, 103106.

Whittaker, A.C, Cowie P.A., Attal, M., Tucker G.E., Roberts, G., 2008, Decoding temporal and spatial patterns of fault uplift using transient river long-profiles, Geomorphology, 100, 506-526, doi:10.1016/j.geomorph.2008.01.018.

Whittaker, A.C., Duller, R.A., Springett, J., Smithells, R., Whitchurch A.L., Allen, P.A., 2011. Decoding downstream trends in stratigraphic grain-size as a function of tectonic subsidence and sediment supply, Geological Society of America Bulletin, 123, 1363-1382. 
Whittaker A., Boulton S., 2012. Tectonic and climatic controls on knickpoint retreat rates and landscape response times. Journal of Geophysical Research 117: F02024, doi:10.1029/2011JF002157.

Wickert A.D., Mitrovica J.X., Williams, C., Anderson, R.S., 2013. Gradual demise of a thin southern Laurentide ice sheet recorded by Mississippi drainage. Nature: 502, 668-671.

Willgoose, G.R., Bras, R.L., Rodriguez-Iturbe I., 1991. A physically based coupled network growth and hillslope evolution model: 1 Theory. Water Resources Research 27, 1671-1684.

Ziliani, L., Surian, N., Coulthard, T.J., Tarantola, S., 2013. Reduced-complexity modeling of braided rivers: Assessing model performance by sensitivity analysis, calibration, and validation. Journal of Geophysical Research: Earth Surface 118, 2243-2262.

Zolezzi, G., Luchi, R., Tubino, M., 2012. Modeling morphodynamic processes in meandering rivers with spatial width variations . Reviews of Geophysics 50 Article number RG4005 DOI: 10.1029/2012RG000392 

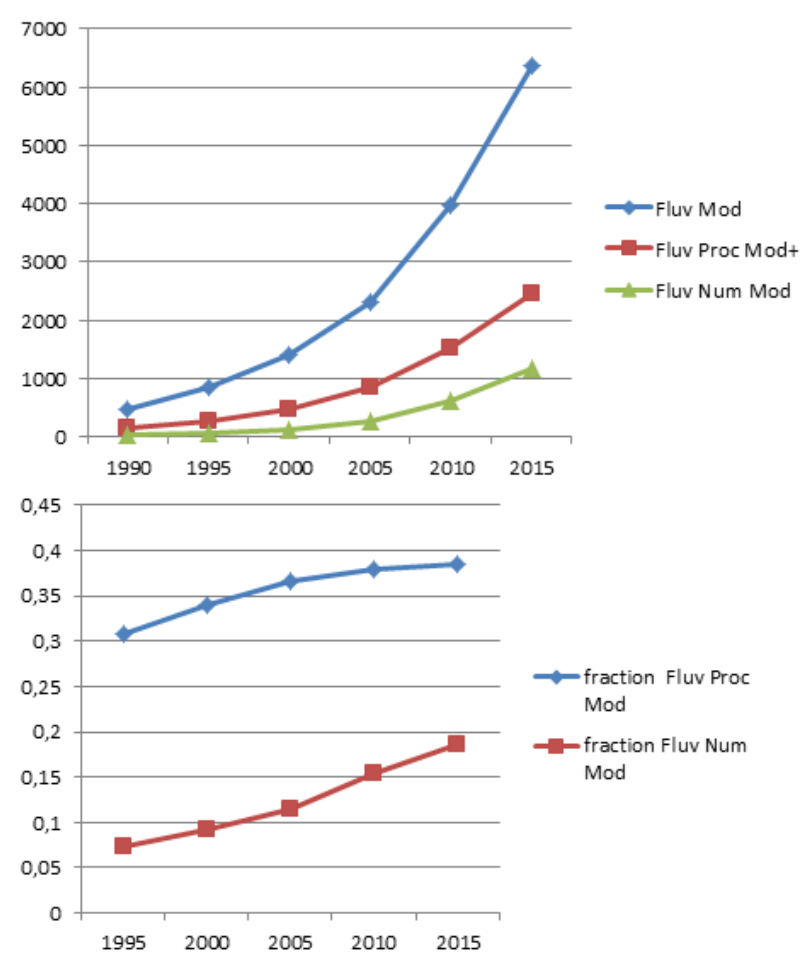

Fig 1. Upper graph a: number of scientific publications cummulative in time with specific key words. Lower graph b: fraction of process models and numerical models of the 'Fluvial Model' group (source: SCOPUS data base August 2016) 


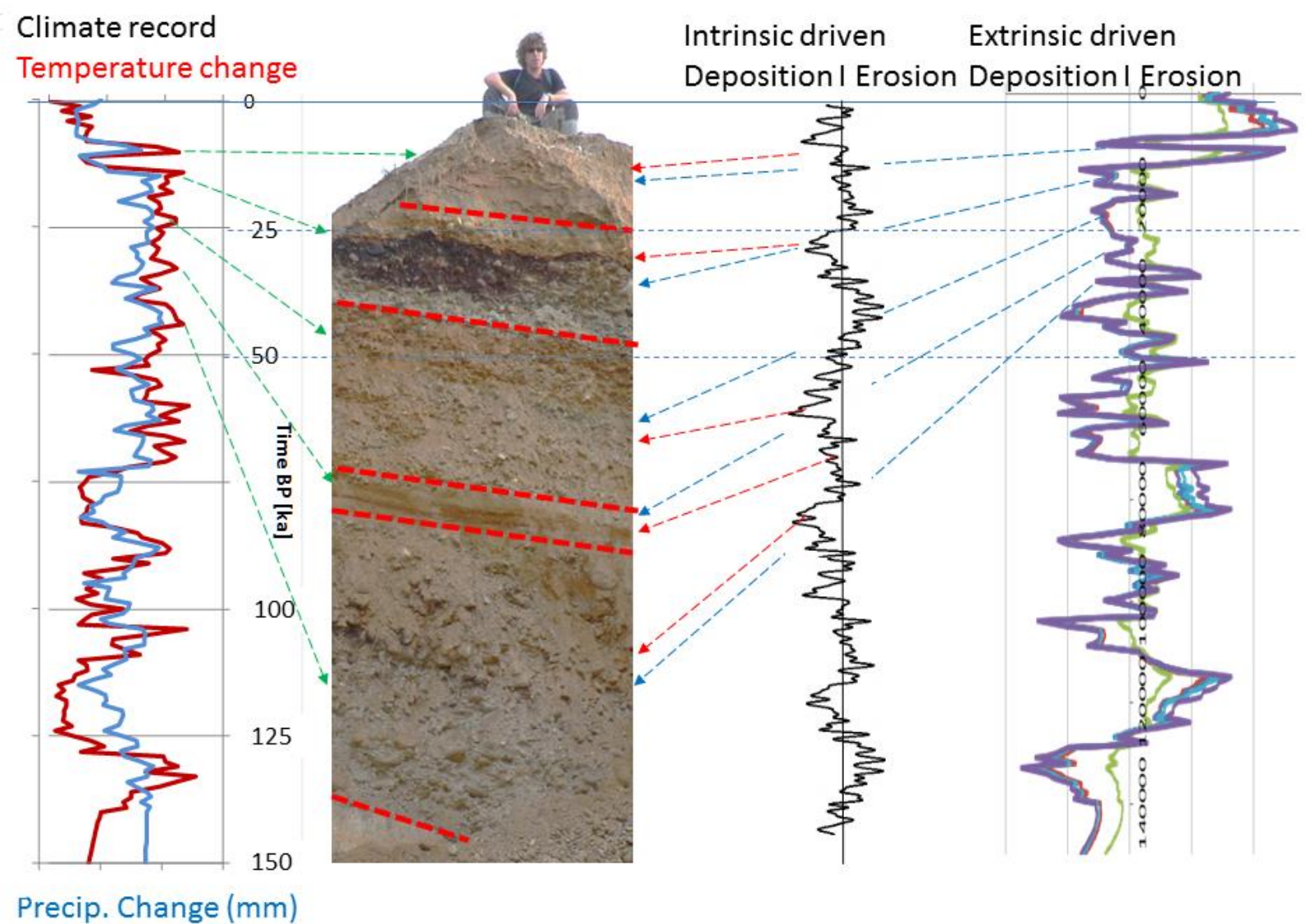

Figure 2

Figure 2 .

An existing climate record for France (example is temperature (red) and precipitation (blue) deviations over the last $150 \mathrm{ka}$ (Guiot et al., 1989; 1993)) is given at the left hand side. This climate curve is remodeled into an externally driven fluvial erosion/deposition curve using the FLUVER2 model a curve (purple curve, right hand side, (see Veldkamp et al., 2016)). As a result the interpretations using this curve (see blue arrows), correlating depositional events to sedimentary units, demonstrates some deviations especially for the older units. When the intrinsically driven erosion/deposition curve is calculated even more deviations can be observed (see red arrows). 


\begin{tabular}{|l|l|l|l|}
\hline $\begin{array}{l}\text { Table 1a: } \\
\text { Key words: }\end{array}$ & Fluvial Model & $\begin{array}{l}\text { Fluvial Process } \\
\text { Model (38.5\% of } \\
\text { fluvial model group) }\end{array}$ & $\begin{array}{l}\text { Fluvial Numerical } \\
\text { Model (18.4\% of } \\
\text { fluvial model group) }\end{array}$ \\
\hline & 6639 & 2557 & 1222 \\
\hline + Control & $1121(16.9 \%)$ & $480(18.8 \%)$ & $203(16.6 \%)$ \\
\hline + Environment & $1454(21.9 \%)$ & $593(23.2 \%)$ & $220(18.0 \%)$ \\
\hline + Climate & $864(13.0 \%)$ & $372(14.5 \%)$ & $137(11.2 \%)$ \\
\hline + Tectonic & $804(12.1 \%)$ & $320(12.5 \%)$ & $123(10.0 \%)$ \\
\hline + Sea Level & $501(7.5 \%)$ & $179(7.0 \%)$ & $82(6.7 \%)$ \\
\hline+ Base Level & $319(4.8 \%)$ & $123(4.8 \%)$ & $47(3.8 \%)$ \\
\hline & $87(1.3 \%)$ & $42(1.6 \%)$ & $39(3.2 \%)$ \\
\hline+ Non linear & $53(0.8 \%)$ & $30(1.2 \%)$ & $16(1.3 \%)$ \\
\hline+ Intrinsic & & &
\end{tabular}

\begin{tabular}{|l|l|l|}
\hline Table 1b: & $\begin{array}{l}\text { 17 FLAG dedicated } \\
\text { special issues }\end{array}$ & $\begin{array}{l}\text { FLAG meeting abstracts, last six } \\
\text { meetings }\end{array}$ \\
\hline $\begin{array}{l}\text { Total papers/abstracts } \\
\text { considered }\end{array}$ & 187 & 276 \\
\hline Dedicated to modelling & $16(8.5 \%)$ & $26(9.4 \%)$ \\
\hline
\end{tabular}

Table 1a: Inventory of publications in SCOPUS data base using keywords. Three main groups of key words. 'Fluvial Model', 'Fluvial Process Model', 'Fluvial Numerical Model'. The + key words are added to these three groups individually. Numbers indicate number of all publications in data base (August 2016), ercentages indicate share within each main group.

Table 1b: counted papers and abstracts in FLAG dedicated special issues and Abstracts of last six FLAG meetings. See http://tolu.giub.uni-bonn.de/herget/FLAG/ for documentation. 


\begin{tabular}{|c|c|c|c|c|c|}
\hline Model name & Key papers & Inputs & Outputs & $\begin{array}{l}\text { Relevant Fluvial archive applications cited in } \\
\text { main text }\end{array}$ & Website: \\
\hline $\begin{array}{l}\text { CHILD } \\
\text { 2D landscape } \\
\text { evolution } \\
\text { model TIN } \\
\text { based model }\end{array}$ & $\begin{array}{l}\text { Tucker et al., } \\
2001 .\end{array}$ & $\begin{array}{l}\text { Topography, uplift rate- } \\
\text { "climate" - there are a range of } \\
\text { rainfall models and inputs, } \\
\text { including stochastic } \\
\text { distributions, bedrock } \\
\text { strength/erodibility and a } \\
\text { choice of different fluvial and } \\
\text { hillslope erosion laws }\end{array}$ & $\begin{array}{l}\text { Changing topography in } \\
\text { time and space. From } \\
\text { this, river long profiles, } \\
\text { sediment fluxes, erosion } \\
\text { rates can be derived. }\end{array}$ & $\begin{array}{l}\text { (Attal, et al, 2008): effect of active normal } \\
\text { faulting on channel long profiles and channel } \\
\text { width record. } \\
\text { (Whittaker, et al., 2008): Central Apennines of } \\
\text { Italy } \\
\text { (Van Balen et al., 2010): effect of climate } \\
\text { change on sediment fluxes and grain size sorting } \\
\text { (Rhine-Meuse rivers) }\end{array}$ & $\begin{array}{l}\frac{\mathrm{http}: / / \text { csdms.colora }}{\text { do.edu/wiki/Model }} \\
\underline{\text { CHILD }}\end{array}$ \\
\hline $\begin{array}{l}\text { FLUVER2 } \\
\text { 1D longitudinal } \\
\text { nodal model }\end{array}$ & $\begin{array}{l}\text { Veldkamp and } \\
\text { Van Dijke, } \\
2000 .\end{array}$ & $\begin{array}{l}\text { Initial longitudinal profile, } \\
\text { Precipitation and temperature } \\
\text { curve, } \\
\text { Tectonic movement rates, base } \\
\text { level curve }\end{array}$ & $\begin{array}{l}\text { Profile evolutions maps, } \\
\text { Sediment fluxes, vertical } \\
\text { floodplain dynamics }\end{array}$ & $\begin{array}{l}\text { (Tebbens et al., 2000): Meuse river in the } \\
\text { Netherlands. } \\
\text { (Veldkamp et al., 2002): Aller river (Weser } \\
\text { tributary) in Germany, } \\
\text { (Viveen et al., 2013): Miño river in Portugal and } \\
\text { Spain } \\
\text { (Geach et al., 2015): Tabernas river in south- } \\
\text { eastern Spain } \\
\text { (Veldkamp et al., 2016): Allier - Loire river in } \\
\text { France }\end{array}$ & $\begin{array}{l}\text { http://www.wageni } \\
\text { ngenur.nl/en/Exper } \\
\text { tise- } \\
\text { Services/Chair- } \\
\text { groups/Environme } \\
\text { ntal-Sciences/Soil- } \\
\text { Geography-and- } \\
\text { Landscape- } \\
\text { Group/Research/F } \\
\text { LUVER2.htm }\end{array}$ \\
\hline $\begin{array}{l}\text { CAESAR Grid } \\
\text { based model } \\
\text { focused on } \\
\text { landscape and } \\
\text { floodplain } \\
\text { dynamics }\end{array}$ & $\begin{array}{l}\text { Van de Wiel et } \\
\text { al., 2007, } \\
\text { Coulthard et al., } \\
2013 \text {. }\end{array}$ & $\begin{array}{l}\text { Topography (DEM), Climate } \\
\text { (precipitation time series), } \\
\text { Grainsize, Land cover } \\
\text { (reflected in hydrology). }\end{array}$ & $\begin{array}{l}\text { time series of water and } \\
\text { sediment at catchment } \\
\text { outlet, DEM's of surface } \\
\text { at whatever time required, } \\
\text { Surface and subsurface } \\
\text { grainsize }\end{array}$ & $\begin{array}{l}\text { (Coulthard et al, 2002): Records of UK } \\
\text { Holocene river activity } \\
\text { (Coulthard et al., 2005): Importance of location } \\
\text { of fluvial archive within drainage basin. } \\
\text { (Coulthard and Van de Wiel, 2007; 2013): Role } \\
\text { of non linear processes in generating false } \\
\text { alluvial archive signals }\end{array}$ & $\begin{array}{l}\frac{\text { http://www.coultha }}{\text { rd.org.uk/CAESA }} \\
\frac{\text { R.html }}{\text { and }} \\
\frac{\text { http://www.coultha }}{\text { rd.org.uk/CAESA }} \\
\text { RLisflood.html }\end{array}$ \\
\hline $\begin{array}{l}\text { LAPSUS } \\
\text { (2002) Grid } \\
\text { based } \\
\text { landscape } \\
\text { model focused } \\
\text { on hill slope } \\
\text { dynamics }\end{array}$ & $\begin{array}{l}\text { Schoorl et al., } \\
2000 ; 2002 .\end{array}$ & $\begin{array}{l}\text { Altitude (DEM), rainfall } \\
\text { (climate), tectonics, lithology } \\
\text { (erodibility, infiltration) }\end{array}$ & $\begin{array}{l}\text { Timeseries of: DEMs, } \\
\text { maps of erosion, } \\
\text { sedimentation, discharge, } \\
\text { data on mean erosion - } \\
\text { sedimentation rates for } \\
\text { locations, areas, zones at } \\
\text { any time t during } \\
\text { simulation. }\end{array}$ & $\begin{array}{l}\text { (Schoorl et al., 2014): Intrinsic sediment pulses, } \\
\text { changing locations of erosion and sedimentation } \\
\text { causing autogenous terraces . } \\
\text { (Claessens et al. 2006): coupling landslides } \\
\text { through the river network to a sediment archive. } \\
\text { (Temme and Veldkamp, 2009): Late Pleistocene } \\
\text { colluvial record South Africa } \\
\text { (Baartman et al 2012a, 2012b): Late Pleistocene } \\
\text { colluvial record South Spain with historical } \\
\text { tillage translocation. } \\
\text { (Van Gorp 2013, 2015): spatial temporal effects } \\
\text { on fluvial landscape development due to lava } \\
\text { damming (western Anatolia). }\end{array}$ & $\underline{\underline{\text { http://www.lapsus }}}$ \\
\hline $\begin{array}{l}\text { SELF- } \\
\text { SIMILARITY } \\
\text { DOWNSTREA } \\
\text { M FINING } \\
\text { MODEL }\end{array}$ & $\begin{array}{l}\text { Duller et al., } \\
2010 . \\
\text { (developed } \\
\text { from Fedele \& } \\
\text { Paola, 2007, } \\
\text { JGR) }\end{array}$ & $\begin{array}{l}\text { Sediment flux, spatial } \\
\text { distribution of accommodation, } \\
\text { grain size in the supply. }\end{array}$ & $\begin{array}{l}\text { Spatial distribution of } \\
\text { mean grain size in the } \\
\text { deposit, standard } \\
\text { deviation of grain sizes }\end{array}$ & $\begin{array}{l}\text { (Whittaker, et al., 2011): downstream trends in } \\
\text { stratigraphic grain-size as a function of tectonic } \\
\text { subsidence and sediment supply } \\
\text { (D'Arcy et al., 2016): Pleistocene to Recent } \\
\text { climate-driven sediment fluxes and grain size } \\
\text { changes. }\end{array}$ & $\begin{array}{l}\frac{\text { http://www.imperia }}{\text { lac.uk/people/a.wh }} \\
\text { littaker; }\end{array}$ \\
\hline $\begin{array}{l}\text { COUPLED } \\
\text { CATCHMENT } \\
\text { BASIN } \\
\text { MODEL }\end{array}$ & $\begin{array}{l}\text { Armitage et al., } \\
2011,2013 \text {. }\end{array}$ & $\begin{array}{l}\text { Catchment: length, size, } \\
\text { hillslope diffusivity, rainfall } \\
\text { parameter, non-linear fluvial } \\
\text { transport co-efficient, erosion } \\
\text { exponent, n, } \\
\text { Basin: subsidence/uplift rate in } \\
\text { time and space; sediment flux } \\
\text { from catchment output, above, } \\
\text { grain size estimate. }\end{array}$ & $\begin{array}{l}\text { Long profile evolution in } \\
\text { time and space; sediment } \\
\text { flux in time and space, } \\
\text { stratigraphic output of } \\
\text { volumes and sedimentary } \\
\text { grain sizes. }\end{array}$ & $\begin{array}{l}\text { (Armitage et al., 2015): application - Spanish } \\
\text { Pyrenees. }\end{array}$ & $\begin{array}{l}\underline{\text { http://www.ipgp.fr/ }} \\
\text { en/user/584 }\end{array}$ \\
\hline Delft3D & $\begin{array}{l}\text { Lesser et al., } \\
\text { 2004; Roelvink } \\
\text { 2006,. }\end{array}$ & $\begin{array}{l}\text { Topography, bathymetry, } \\
\text { fluvial discharge, sediment } \\
\text { concentrations, wave climate, } \\
\text { tidal regime. }\end{array}$ & $\begin{array}{l}\text { Topography, bathymetry, } \\
\text { stratigraphy, } \\
\text { hydrodynamic } \\
\text { information in time (flow } \\
\text { velocity, sediment } \\
\text { transport rates, deposition } \\
\text { rates, erosion rates) }\end{array}$ & $\begin{array}{l}\text { (Geleynse et al 2010, 2011): Controls on river } \\
\text { delta formation }\end{array}$ & $\underline{\underline{h t t p: / / o s s . d e l t a r e s . n}}$ \\
\hline $\begin{array}{l}\text { Lower Crustal } \\
\text { Flow Model }\end{array}$ & $\begin{array}{l}\text { Westaway, } \\
1998,2002 .\end{array}$ & $\begin{array}{l}\text { Estimated rates of surface } \\
\text { processes, crustal properties } \\
\text { such as crustal thickness, } \\
\text { thickness of the mobile lower- } \\
\text { crustal layer, and the effective } \\
\text { viscosity of the mobile lower- } \\
\text { crustal layer. }\end{array}$ & $\begin{array}{l}\text { Predicted rates vertical } \\
\text { crustal motion. It provides } \\
\text { age predictions for fluvial } \\
\text { terraces and as stresses at } \\
\text { depth within the crust, } \\
\text { rates of flow within the } \\
\text { mobile lower-crustal } \\
\text { layer, etc, but these } \\
\text { quantities are not directly } \\
\text { observable. }\end{array}$ & $\begin{array}{l}\text { (Westaway, 2004): application Loire/Seine } \\
\text { Trance } \\
\text { (Westaway et al., 2002): Application Thames } \\
\text { UK } \\
\text { (Westaway et al., 2003): Application India } \\
\text { (Westaway and Bridgland, 2014): global } \\
\text { synthesis of applications. }\end{array}$ & Not available \\
\hline TISC & Garcia- & Initial topography, erodibility, & Changing topography in & (Stange et al. , 2016): The Ebro river sytem & ogle. \\
\hline
\end{tabular}




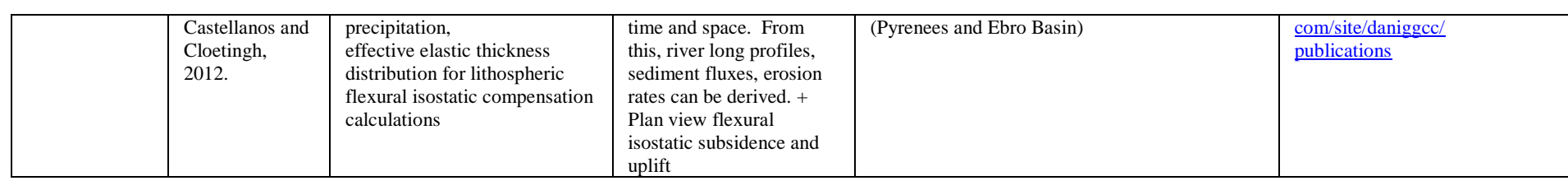

